\title{
INFLUENCE OF THE ENVIRONMENTAL POLLUTION ON THE DISTRIBUTION AND POLYMERIZATION DEGREE OF CELLULOSE IN BARK AND WOOD FROM SCOTS PINE (PINUS SYLVESTRIS L.) STEM
}

\author{
Donata Krutul, Andrzej Radomski, Andrzej Antczak, Michae Drożdżek \\ Teresa Keosińska, Dominika Szadkowska, Janusz Zawadzki \\ Warsaw University of Life Sciences \\ Poland \\ (Received Jule 2020)
}

\begin{abstract}
The pine stems were cut from three different polluted environments - Ist trees degradation degree (weak pollution), II ${ }^{\text {nd }}$ trees degradation degree (strong pollution) and III ${ }^{\text {rd }}$ trees degradation degree (connected with very strong pollution). On the basis of obtained results it was stated that environmental pollution caused changes in late wood participation, as well as distribution of cellulose on the stem cross- and longitudinal section. It also changed cellulose content in bark from the butt-end section, which was about $26 \%$ regardless the degradation degree. The environmental pollution caused also an increase of viscometric average polymerization degree of cellulose in heartwood in relation to heartwood adjacent sapwood and sapwood from butt-end section. Regardless the degradation degree, cellulose polymerization degree in heartwood adjacent sapwood from the middle part of the stem was higher in comparison to sapwood and heartwood. Moreover, the environmental pollution caused the increase of viscometric average polymerization degree of cellulose in bark. The polymerization degree of cellulose in bark from the butt-end section of III ${ }^{\text {rd }}$ degradation degree stems was $22 \%$ and $23 \%$ higher in comparison to the Ist $^{\text {and }}$ IInd degradation degree.
\end{abstract}

KEYWORDS: Pine, sapwood, sapwood adjacent heartwood, cellulose, polymerization degree.

\section{INTRODUCTION}

Trees are a good archive of changes in the ecosystem in which they are grown. They are exposed to climate change and pollution. Changes in the ecosystem can affect the chemical structure of the wood (Sensula et al. 2015, Waliszewska et al. 2019). Pine wood is the basic raw material for pulp production and more, that is why the studies of holocellulose, $\alpha$-cellulose 
and cellulose on the cross- and longitudinal section of pine stem is an important factor studied by many researchers (Harwood 1971, Uprichard 1971, Krutul 1994, Fengel and Wegener 2003, Willför et al. 2005, Waliszewska et al. 2015, Antczak et al. 2016, Zawadzki et. al. 2016, Funda et al.2020). According to Krutul(1994), cellulose content in 110-year-old pine stemsincreases from pith perimeter, regardless the stem height. Differences in cellulose content between sapwood and heartwood are the most significant in butt-end section and up to the height of $20 \mathrm{~m}$. Whereas, at higher level these contents differ only by about $15 \%$.

Depending on environmental pollution degree, higher of lower changes in content and distribution of mineral substances and extractives may be observed, as well as structural components on the cross- and longitudinal section. Changes caused by the environmental pollution are related to decrease of annual increments width and the increase of late wood participation in comparison to unpolluted wood (Sensuła et al. 2017, Cindoruk et al. 2020). According to Krutul (1994), in 110-year-old pine wood, gained from the unpolluted environment, higher correlation coefficient between cellulose content and late wood participation may be found for samples from cross-sections from the height of 6 and $10 \mathrm{~m}$ (correspondingly 0.8466 and 0.9130 ) in relation to samples gained from $2 \mathrm{~m}$ height (0.5874). The dependence between cellulose content and late wood participation along the stem occurs in the group of annual increments $1^{\text {st }}-10^{\text {th }}$ ( from the perimeter), with the correlation coefficient of 0.81 (Krutul 1994).

Krutul et al. (2006) performed studies on the influence of the heat and power plant on the cellulose content in wood, branches, roots and bark of Scots pine. Samples for the analysis were collected 1 and $21 \mathrm{~km}$ far from the emission source. It was stated that cellulose content is lower in pith adjacent wood in relation to sapwood both in butt-end and middle section, as well as in the top of the stem. Such a distribution was also denoted in former paper of Krutul (1994), concerning pine trees growing in the environment unpolluted with any industrial emissions. According to Krutul et al. (2006) cellulose content in bark from trees growing in the distance of 1 and $21 \mathrm{~km}$ from the heat and power plant equals $21.9 \%$ and $23.0 \%$ correspondingly, and does not much differ from the literature data (23.1\% - Fengel and Wegener 2003, 22.2\% - Räisänen and Athanassiadis 2013, 20.2\% - Rowell 2005). Industrial emissions caused by heat and power plants also did not influence the cellulose content in pine wood in relation to results obtained for samples obtained from unpolluted environment (Krutul et al. 2006).

Polymerization degree is the important parameter of cellulose and it may be examined with different methods including viscometry. According to Zawadzki et al. (2006), viscometric average polymerization degree of cellulose isolated from Scots pine sapwood is in the range of 549-553 (isolated with Cross-Bevan method), 497-502 (Kürschner-Hoffer method) and 471-482 (Seifert method). It means that isolation with Seifert method causes higher degree degradation in comparison to other methods. That is why viscometric average polymerization degree of cellulose may be the indicator testifying of its degradation under the influence of physical, chemical and mechanical factors. The highest percent difference in the viscometric average polymerization degree was denoted for sapwood adjacent heartwood and in sapwood in relation to the pith adjacent sapwood. It equals correspondingly $27 \%$ to $45 \%$ and $35 \%$ to $48 \%$ (Krutul 1988). However, it must be emphasized that viscometric average polymerization degree may be the best parameter for comparisons.

The aim of this paper is to examine the influence of the pollution caused by "Kędzierzyn" Nitrogen Industrial Plant on the cellulose content and its viscometric average polymerization degree on the cross- and longitudinal section of Scots pine stems. Nitrogen Industrial Plant "Kędzierzyn" has performed production of ammonia, nitric acid and nitrogenous fertilizers since 1954. Phthalic acid anhydride waxes and fatty acids were additional products. Heat and power station was also built in the area. Since the beginning of 80 's, condition of the environment has 
begun to improve because of eco-policy. For example, the emission of the ammonia in Nitrogen Industrial Plant in 1991 was 4000 tons and in 2005 about 500 tons.

\section{MATERIAL AND METHODS}

The research material of Scots pine stems were collected from $V^{\text {th }}$ Silesian region in December. Three about 80-year-old trees were cut from each environments - characterized with III ${ }^{\text {rd }}$ trees degradation degree (connected with very strong pollution), IInd trees degradation degree (strong pollution) and It trees degradation degree (weak pollution). The degree of trees degradation in studied zones was defined and related to the distance between the trees and the Nitrogen Industrial Plant "Kędzierzyn". Trees from the $\mathrm{I}^{\text {st }}$ zone were within $25 \mathrm{~km}$ of the Nitrogen Industrial Plant, from the II ${ }^{\text {nd }}$ zone were within $15 \mathrm{~km}$ of the Nitrogen Industrial Plant and trees from the IIIrd zone were within $1 \mathrm{~km}$ of the Nitrogen Industrial Plant.

The $300 \mathrm{~mm}$ thick disks were cut from each analyzed stem (from butt-end section, halfheight and top part). Following zones were distinguished on disks cross-section: sapwood, heartwood adjacent sapwood and heartwood. In the top part of the disk diameter only sapwood and heartwood were distinguished. In butt-end and middle sections bark was collected too. Width measurement of the annual rings and the proportion of late wood were made according to the standard PN-55/D-04110. Samples were extracted before further analysis in the ethanolbenzene mixture (1:1) in the Soxhlet apparatus. Cellulose was isolated by Kürschner-Hoffer method (Saeman et al. 1954, Krutul 2002).

Viscometric average polymerization degree of the Kürschner-Hoffer cellulose was determined with Ubbelohde method (Zawadzki et al. 2006). Viscometer with the capillary no. I was used, CuEN (cupriethylendiamine hydroxide) was applied as the cellulose solvent. The value of the viscometric average polymerization degree was calculated on the basis

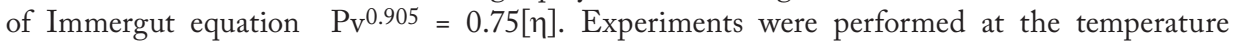
of $25^{\circ} \mathrm{C}$. The Viscoclock timer was used for time measurements. Three experiments of each sample were done and standard deviation were calculated.

\section{RESULTS AND DISCUSSION}

The rings width showed large fluctuations depending on the habitat and growth conditions of the tree (Matulewski et al. 2019). The annual rings width is a criterion that allows assessment of the wood technical properties. It is assumed that wood with an annual ring width less than $3 \mathrm{~mm}$ is narrow-grained. In high-quality wood, the annual rings narrow gradually and evenly from the pith to the bark of the trunk. Based on the data presented in Figs. 1a,b,c, it can be concluded that the tested pine wood was narrow-grained. The width of annual rings did not exceed $3 \mathrm{~mm}$, regardless of the environmental contamination. Sapwood and sapwood adjacent heartwood was characterized by narrower annual rings than heartwood, regardless of the environmental contamination and the height. Sapwood annual rings in Scots pine from very strong polluted area were from $40 \%$ to $60 \%$ narrower than sapwood annual rings in Scots pine from strong and weak polluted areas. Annual rings in sapwood adjacent heartwood from middle section were characterized from $40 \%$ to $60 \%$ smaller width than annual rings in sapwood and about two time smaller than annual rings in heartwood. Heartwood from the top section of the Scots pine trunks were characterized from $40 \%$ to $90 \%$ wider annual rings than sapwood from the same trunk section, regardless of the environmental contamination (Fig. 1). 


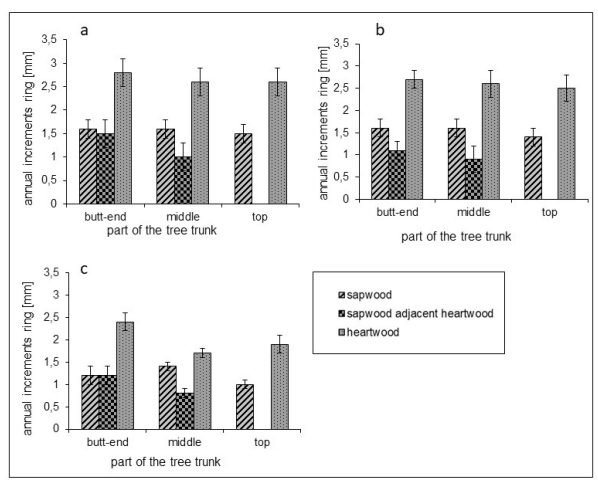

Fig.1: Annual increments participation in analyzed samples of Scots pine wood (PinussylvestrisL.); a-Istdegradation degree(weakpollution), b-IInddegradation degree(strongpollution), c- IIIrd degradation degree (very strong pollution).

Wood density as well as compression strength and other strength parameters are proportionally related with the participation of late wood. As it arises from data presented in the Fig. 2, late wood participation in the butt-end section from the stem of III ${ }^{\text {rd }}$ degradation degree was $35 \%$ and $30 \%$ higher in sapwood in relation to correspondingly $\mathrm{I}^{\text {st }}$ and II ${ }^{\text {nd }}$ degradation degree stems. This value in the heartwood adjacent sapwood and heartwood from middle stem section was lower in III ${ }^{\text {rd }}$ degradation degree stems in comparison to Ist $^{\text {and }}$ IInd degradation degree stems. Late wood participation was similar for all degradation degrees in the top part of the stem. The results obtained are consistent with the data of Krutul (1994). According to these literature data, in 110-year-old pine trees, late wood participation increases from pith to bark. The largest proportion of late wood was characterized by wood at a height of $2 \mathrm{~m}$ from the base of the trunk. In sapwood from the Scots pine trunks from weak and strong polluted areas late wood participation was similar in the all height zones. Whereas, in the Scots pine trunks from very strong polluted areas, sapwood was characterized about $20 \%$ less late wood participation in top part of trunk compared to butt-end and middle part of trunk. The heartwood from top part of trunks was characterized less late wood participation than in the middle and butt-end parts of trunk, regardless of the environmental contamination (Fig. 2).

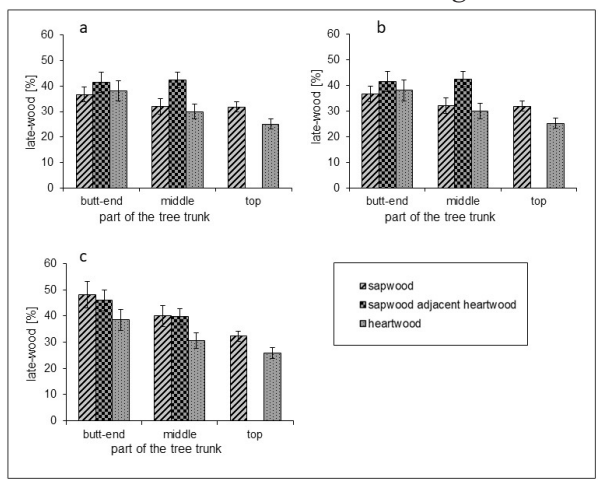

Fig.2: Late wood participation in analyzed samples of Scott pine wood (Pinus sylvestris L.); a- Ist degradation degree (weak pollution), b - IInd degradation degree (strong pollution), c- IIIrd degradation degree (very strong pollution). 
Fig. 3 presents cellulose content in analyzed samples of wood and bark. Cellulose content in sapwood was higher than in heartwood, regardless the height and degradation degree. Cellulose content in sapwood from the butt-end section was $5 \%$ higher in relation to heartwood (Ist degradation degree) or $6 \%$ higher (IInd and III ${ }^{\text {rd }}$ degradation degree). Butt-end section from III ${ }^{\text {rd }}$ degradation degree stem contained more cellulose and late wood in relation to I $^{\text {st }}$ and II $^{\text {nd }}$ degradation degree samples. Sapwood from the middle part of the III ${ }^{\text {rd }}$ degradation degree stem contained more late wood and about $20 \%$ more cellulose in relation to samples of $\mathrm{I}^{\text {st }}$ degradation degree. Moreover sapwood from the middle part of the III ${ }^{\text {rd }}$ degradation degree stem contained almost similar to samples of II ${ }^{\text {nd }}$ degradation degree late wood participation, but cellulose content was higher in comparison to other degradation degrees samples. Heartwood contained similar late wood and cellulose content regardless the degradation degree. Late wood participation from the sapwood from the top part of II ${ }^{\text {nd }}$ degradation degree stem was similar and cellulose content was about $5 \%$ lower in relation to samples from Ist and IIIrd degradation degree. Heartwood, regardless the degradation degree, contained similar late wood and cellulose.

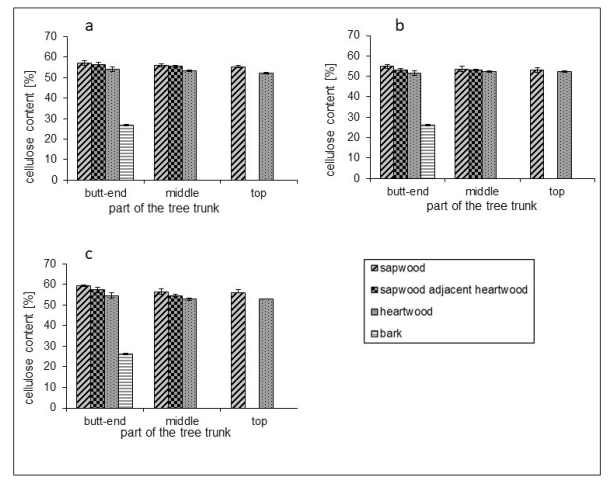

Fig.3: Cellulose content in wood and bark of analyzed samples of Scots pine stems (Pinus sylvestris L.); a- Ist degradation degree (weak pollution), $b$ - IInd degradation degree (strong pollution), c-IIIrd degradation degree (very strong pollution).

Summarizing it may be stated that the environmental pollution did not influence the distribution of cellulose on the stem cross-section, what is consistent with Krutul (1994). It was denoted that cellulose content in 110-year-old Scots pine increased in the direction from the pith to perimeter, regardless the height. However, environmental pollution could influenced the content and distribution of cellulose on the longitudinal section and late wood participation. Cellulose content in bark from the butt-end section was similar regardless the degradation degree. It equals $26.8 \%, 26.0 \%$ and $26.2 \%$ for correspondingly Ist, II ${ }^{\text {nd }}$ and IIIrd degradation degree. Cellulose content in bark was about $50 \%$ lower in relation to wood, regardless the environmental pollution. According to Krutul et al. (2006), cellulose content in Scots pine stems collected in the distance 1 and $21 \mathrm{~km}$ from the heat and power plant was on the level 21.8\% and 23.0\% respectively. Räisänen and Athanassiadis (2013) denoted that Scots pine bark contains $22.2 \%$ of cellulose, while Fengel and Wegener (2003) determined this value to be $23.1 \%$. The environmental pollution could also influenced the cellulose content in bark which was about 15\% higher in relation to Räisänen and Athanassiadis (2013) data and about $12 \%$ higher in comparison to values denoted by Fengel and Wegener (2003). 


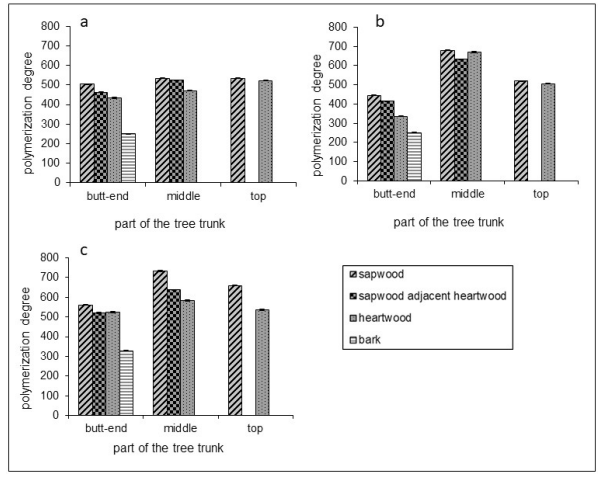

Fig. 4: Viscometric average polymerization degree of cellulose in analyzed pine stem zone; $a^{-} I^{\text {st }}$ degradation degree (weak pollution), $b-I I^{\text {nd }}$ degradation degree (strong pollution), $c^{-}$- III ${ }^{r d}$ degradation degree (very strong pollution).

Fig. 4 presents values of the cellulose polymerization degree in analyzed pine stem zones. This value for the cellulose from the III ${ }^{\text {rd }}$ degradation degree wood collected from the butt-end section was higher in relation to other degradation degrees regardless the analyzed zone. In sapwood, heartwood adjacent sapwood and heartwood, the increase of cellulose average polymerization degree from the IIIrd degradation degree samples equaled $17.5 \%, 16.0 \%$ and $5.0 \%$ in relation to Ist degradation degree samples, and $30.0 \%, 19.0 \%$ and $16.0 \%$ in relation to IInd degradation degree samples, correspondingly. In butt-end section, heartwood, the environmental pollution probably caused the increase of the average polymerization degree in relation to heartwood adjacent sapwood and sapwood.

In the middle part of the stem, regardless the degradation degree, cellulose polymerization degree in heartwood adjacent sapwood was higher in comparison to sapwood and heartwood. In IInd degradation degree samples the cellulose polymerization degree was higher than value obtained for other degradation degrees. For the Ist and III ${ }^{\text {rd }}$ degradation degree cellulose polymerization degree in heartwood was higher in relation to sapwood, while in IInd degradation degree samples values for heartwood and sapwood were similar. It must be stated, that environmental pollution probably influenced the viscometric average polymerization degree of cellulose on the wood cross-section. Average polymerization degree of cellulose in sapwood from the top part of the stem was from $2 \%$ to $7 \%$ higher in relation to heartwood in case of Ist and III ${ }^{\text {rd }}$ degradation degree. These values for heartwood and sapwood from IInd degradation degree stem were similar again.

Polymerization degree of cellulose in bark collected from the butt-end section of III ${ }^{\text {rd }}$ degradation degree stems was $22 \%$ and $23 \%$ higher in comparison to the It $^{\text {st }}$ and II $^{\text {nd }}$ degradation degree, correspondingly (Fig. 4). It shows that the environmental pollution probably caused the increase of cellulose viscometric average polymerization degree in bark.

\section{CONCLUSIONS}

Obtained results lead to following statements: (1) The environmental pollution which originate from the Nitrogen Industrial Plant "Kędzierzyn" could caused changes of late wood 
participation. The distribution of cellulose on the cross- and longitudinal section of stems was also could be dependent on the environmental pollution. It also probably caused an increase of viscometric average polymerization degree of cellulose in heartwood in relation to heartwood adjacent sapwood and sapwood from butt-end section. (2) Regardless the degradation degree, cellulose polymerization degree in heartwood adjacent sapwood from the middle part of the stem was higher in comparison to sapwood and heartwood. Also in bark, cellulose polymerization degree probably increased as the result of the environmental pollution.

\section{REFERENCES}

1. Antczak, A., Radomski, A., Drożdżek, M., Zawadzki, J., Zielenkiewicz, T., 2016: Thermal ageing of cellulose with natural and synthetic antioxidants under various conditions. Drewno 59(196): 139-152.

2. Cindoruk, S.S., Sakin, A.E., Tasdemir, Y., 2020: Levels of persistent organic pollutants in pine tree components and ambient air. Environmental Pollution 256: 113418.

3. Dupont, A.L., Mortha, G., 2004: Comparative evaluation of size-exclusion chromatography and viscometry for the characterization of cellulose. Journal of Chromatography A 1026 (1-2): 129-141.

4. Fengel, D., Wegener, G., 1984: Wood (chemistry, ultrastructure, reaction). Walter de Guyter Press. Berlin, New York, 613 pp.

5. Funda, T., Fundová, I., Fries, A., Wu, H.X., 2020: Genetic improvement of the chemical composition of Scots pine (Pinus sylvestris L.) juvenile wood for bioenergy production. GCB Bioenergy 12(10): 848-863.

6. Harwood, V.D., 1971: Variation in carbohydrate analyses in relation to wood age in Pinus radiata. Holzforschung 25(3): 73-77.

7. Krutul, D., 1988: Content of cellulose and some of its properties analyzed on the crossand longitudinal sections of oak trunk. Folia Forestalia Polonica Series B - Wood Science 18: 41-56.

8. Krutul, D., 1994: Variation in cellulose content in the stem of pine wood (Pinus sylvestris L.). Annals of Warsaw University-SGGW. Forestry and Wood Technology 45: 43-49.

9. Krutul, D., 2002: Exercises in wood chemistry and selected issues in organic chemistry. WULS-SGGW Press, Warsaw, Pp 125-127.

10. Krutul, D., Makowski, T., Hrols, J., 2006: Influence of heating power station on the chemical composition of wood, bark, branches and main roots of Scotch pine (Pinus sylvestris L.). Annals of Warsaw University-SGGW. Forestry and Wood Technology 59: 16-23.

11. Krutul, D., Drożdżek, M., Zielenkiewicz, T., Radomski, A., Zawadzki, J., Antczak, A., 2009: Distribution and some properties of cellulose in the stem of oak wood (Quercus petraea Liebl.). Annals of Warsaw University-SGGW. Forestry and Wood Technology 68: 436-443.

12. Matulewski, P., Buchwal, A., Makohonienko, M., 2019: Higher climatic sensitivity of Scots pine (Pinus sylvestris L.) subjected to tourist pressure on a hiking trail in the Brodnica Lakeland, NE Poland. Dendrochronologia 54: 78-86.

13. PN-55/D-04110, 1955: Physical and mechanical properties of wood. Study on the percentage of early and late wood.

14. Räisänen, T., Athanassiadis, D., 2013: Basic chemical composition of the biomass components of pine, spruce and birch. Forest Refine. Finnish Forest Research Institute, 3 pp. 
15. Rowell, R.M., Pettersen, R., Han, J.S., Rowell, J.S., Tshabalala, M.A., 2005: Cell wall chemistry. In: Handbook of wood chemistry and wood composites (ed. Rowell R.M.). CRC Press. Boca Raton, Pp 35-74.

16. Saeman, J.F., Moore, W.E., Mitchell, R.L., Millet, M.A., 1954: Techniques for the determination of pulp constituents by quantitative paper chromatography. TAPPI 37: 336-343.

17. Sensuła, B., Wilczyński, S., Monin, L., Allan, M., Pazdur, A., Fagel, N., 2017: Variations of tree ring width and chemical composition of wood of pine growing in the area nearby chemical factories. Geochronometria 44(1): 226-239.

18. Sensuła, B., Wilczyński S., Opała, M., 2015: Tree growth and climate relationship: dynamics of Scots pine (Pinus sylvestris L.). Growing in the near-source region of the combined heat and power plant during the development of the pro-ecological strategy in Poland. Water Air Soil Pollution 226 (7): 220-236.

19. Uprichard, J.M., 1971: Cellulose and lignin content in chemical composition, density and tracheid length. Holzforschung 25(4): 97-105.

20. Waliszewska, B., Mleczek, M., Zborowska, M., Goliński, P., Rutkowski, P., Szenter, K., 2019: Changes in the chemical composition and the structure of cellulose and lignin in elm wood exposed to various forms of arsenic. Cellulose 26(10): 6303-6315.

21. Waliszewska, B., Prądzyński, W., Zborowska, M., Stachowiak-Wencek, A., Waliszewska, H., Spek-Dźwigała, A., 2015: The diversification of chemical composition of pine wood depending on the tree age. Annals of Warsaw University-SGGW. Forestry and Wood Technology 91: 182-187.

22. Willför, S., Sundberg, A., Hemming, J., Holmbom, B., 2005: Polysaccharides in some industrially important softwood species. Wood Science and Technology 39(4): 245-57.

23. Zawadzki, J., Gawron, J., Antczak, A., Kłosińska, T., Radomski, A., 2016: The influence of heat treatment on the physico-chemical properties of pinewood (Pinus sylvestris L.). Drewno 59(196): 49-57.

24. Zawadzki, J., Radomski, A., Antczak, A., Drożdżek, M., 2006: The influence of cellulose determination methods on viscometric degree of polymerization. Annals of Warsaw University-SGGW. Forestry and Wood Technology 59: 405-409.

\section{Donata Krutul, Andrzej Radomski, Andrzej Antczak*, Michą Drożdżek, Teresa KŁosińska, Dominika Szadkowska, Janusz Zawadzki$$
\text { Warsaw University of Life Sciences }
$$$$
\text { Institute of Wood Sciences And Furniture }
$$$$
\text { NoWOURSYNOWSKA I59 }
$$$$
\text { O2-776 WARSAW }
$$$$
\text { Poland }
$$ \\ *Corresponding author: andrzej_antczak@sggw.edu.pl}

